\title{
TRIAL ADVOCACY TRAINING IN LAW SCHOOL: AN AUSTRALIAN PERSPECTIVE
}

\author{
LES A MCCRIMMON*
}

\section{INTRODUCTION}

Australian law schools are in a unique position. At the end of 1993 less than one-half of the nation's law schools offered a course in trial advocacy. ${ }^{1}$ By way of contrast, in the United States almost all of the accredited law schools offer a basic course in trial advocacy $^{2}$ based on the simulation/critique approach pioneered in the 1970s by the National Institute for Trial Advocacy (NITA). ${ }^{3}$ Hence, Australian law schools are in the enviable position of instituting, further developing, and refining advocacy courses which suit both the educational objectives of the university and the needs of the legal profession.

The following discussion is based on the assumption that advocacy skills can be taught. Mr Justice Hampel, Chairman of the Australian Advocacy Institute and a judge of the Supreme Court of Victoria, has rightly asserted that,

... at last, the myth that advocacy cannot be taught has been finally put to rest. The last fifteen years have seen great developments in the

United States, Canada, Australia and New Zealand in attempts to analyse what makes good persuasive advocacy and how it can be taught. ${ }^{4}$

The argument that effective advocacy skills cannot be taught has run its course. Trial technique has proved to be a highly teachable commodity. ${ }^{5}$ Whether trial advocacy should be taught at the undergraduate level and, if this question is answered in the affirmative, what should be covered in the course, are questions which remain unanswered. Hence, this article will focus on two 
issues: the niche a trial advocacy course should occupy in the undergraduate law school curriculum; and the structure and content of such a course.

\section{THE NICHE A TRIAL ADVOCACY COURSE SHOULD}

\section{OCCUPY IN THE UNDERGRADUATE LAW SCHOOL}

\section{CURRICULUM: PERICLES VS THE PLUMBER REVISITED}

It has been suggested that, at an undergraduate level, "[a] fact trial now and then is well worth while, but only as a relief to the tedium of serious work. ${ }^{6}$ This comment epitomizes the debate aptly labelled by Professor Twining as "Pericles and the Plumber". Educating the lawyer as plumber embraces the image of the lawyer as,

... essentially someone who is master of certain specialized knowledge, "the law," and certain specialized skills. What he [she] needs is a nononsense specialized training to make him [her] a competent technician. A "liberal" education in law for such a functionary is at best wasteful; at worst it can be dangerous. ${ }^{8}$

Educating the lawyer as Pericles embraces the other extreme, namely, “.. the image of the lawyer as Pericles — the law-giver, the enlightened policy maker, the wise judge". ${ }^{9}$ Periodically the practicing legal profession demands that the pendulum swing more in the direction of skills training. ${ }^{10}$ To many academics this shift is incompatible with "educating the lawyer as Pericles". While one may question the validity of this latter assumption, ${ }^{11}$ Australian law schools are responding to this demand, and trial advocacy courses modelled on the method developed by NITA in finding their way into the undergraduate law school curriculum. ${ }^{12}$

\section{The National Institute for Trial Advocacy (NITA) Method}

The National Institute for Trial Advocacy was formed to address the increasing concern in the United States that the legal profession was unleashing incompetent advocates on an unsuspecting public. Then Chief Justice Burger of the United States Supreme Court provided, "a major thrust to improve the competence of the trial bar"13 when his Honour criticised legal education as a cause of inadequate advocacy. ${ }^{14}$ Chief Justice Burger 
noted that, "in spite of all the bar examinations and better law schools, we are more casual about qualifying the people we allow to act as advocates in the courtrooms than we are about licensing our electricians". ${ }^{15}$

NITA held its first workshop in Boulder, Colorado in 1972. Prior to that time there was no nationally recognized, coherent methodology for teaching trial advocacy in the United States. ${ }^{16}$ While variations of the NITA method abound, it may be characterized as a simulation/critique method where the students perform all of the tasks of trial counsel in a simulated courtroom environment. The components of the trial, namely pre-trial preparation, opening address, examination-in-chief and crossexamination of lay and expert witnesses, objections, entry of exhibits, and closing argument, ${ }^{17}$ are dealt with individually ${ }^{18}$ based on fact problems and case files provided to the student. The instructor "role-plays" the judge while another person, usually a student, "role-plays" the witness. The students act as trial counsel. After the presentation, the instructor provides constructive feedback on one or, at the most, two points arising from the student's performance. The presentation may also be videotaped, and later the instructor may review the tape one-on-one with the student. ${ }^{19}$

Prior to the beginning of this decade, advocacy training in Australia was carried out by the uncoordinated efforts of a number of dedicated members of the legal profession. ${ }^{20}$ On the 11th of September 1991, a national response to the "ever growing demand by the Australian legal profession for advocacy training ${ }^{21}$ was made by the Law Council of Australia with the launch of the Australian Advocacy Institute. One of the express aims of the Institute is to train lawyers in the skill of advocacy through the use of the simulation/critique method. ${ }^{22}$ While the Institute takes an interest in advocacy training at all levels, its primary focus to date has been on training practitioners rather than undergraduate law students.

\section{The Use of the NITA Method at the Undergraduate Level}

Concerns have been expressed about the implementation, at the undergraduate level, of a trial advocacy course based on the simulation/critique method. These concerns tend to revolve around 
four related themes.

1 Legal educators argue that the focus of such a course on skills enhancement, rather than on the philosophical and psychological underpinning of those skills, divorces the course from the educational philosophy pervading the balance of law school curriculum. ${ }^{23}$ In the words of one scholar, "skills courses, especially those modelled on the highly successful NITA program, spend too much time on the firing range, too little in cool reflection”. ${ }^{24}$

2 A related, but somewhat different, concern is that the simulation/critique method over-emphasises form, or presentation technique, to the neglect of substantive analysis of the case facts. ${ }^{25}$ Imwinkelried notes that, "the traditionalists' argument is that any course which slights the development of analytic skill "does not merit a position in the law school curriculum”. ${ }^{26}$

3 Following on from number 2 above is the assertion that reliance on a prepared case file is necessarily twodimensional. There is a concern that students cannot be presented with any truly difficult strategic choices due to the limited nature of the materials. ${ }^{27}$ It is argued that,

"[t]he individual, skill-oriented NITA approach reinforces the novice's tendency to focus on the literal, concrete elements of a problem. But novices need to learn how to strategize and plan like trial lawyers, not merely mimic them. Students need to learn how to develop the overall conceptual structures that guide experienced litigators." 28

4 Finally, legal scholars argue that the training of law students based on the simulation/critique method takes place in a vacuum; both moral and experiential. If simulated fact situations are used, there are no real interests to be pursued and no actual truths to be established. ${ }^{29}$ Further, the emphasis on technique may leave little time for reflection on the moral and ethical implications of counsel's conduct. ${ }^{30}$ This concern is exacerbated by the fact that most students will have little or no practical trial experience against which the use of their newly learned skill can be evaluated. In an adversarial process where the emphasis is on winning, advocacy teachers run the risk of "simply teaching paid assassins to aim better"31 without regard to the moral and ethical consequences of their 
actions.

The above criticisms of the NITA method are valid and clearly indicate that an unmodified version should not be incorporated into the law school curriculum. Does it therefore follow that the use of the simulation/critique model should be abandoned at the undergraduate level? The answer is clearly "no”. I am in agreement with Professor Lubet who asserts that,

[u]niversity education in the professions absolutely requires inquiry and investigation that goes beyond simple skills training. The law school trial advocacy class should expand upon the NITA model in precisely the same way that the study of harmonies in music school expands upon piano lessons. ${ }^{32}$

While skills training should remain the primary focus of an undergraduate trial advocacy course, it should not be the only focus.

\section{THE STRUCTURE AND CONTENT OF AN \\ UNDERGRADUATE TRIAL ADVOCACY COURSE}

\section{Course Structure}

The NITA method is the most effective way to impart advocacy skills to undergraduate law students. However, as has been noted above, an expanded version of the model should be incorporated into the curriculum. While the scope of such modifications are only constrained by the inventiveness of the course instructor, it is suggested that the following benchmarks should be kept in mind when structuring the course.

1 Semester vs Intensive: In the United States the two most widely used methods of structuring an undergraduate course in trial advocacy are the "intensive approach" and the "semester approach", ${ }^{33}$ The intensive approach is closely modelled on the NITA method. Students work through case files over an intensive ten-day to three-week period. Emphasis is placed on the workshop where the students "learn by doing". The primary function of the course instructor is to provide constructive feedback, and the lecture/faculty-demonstration component is small. ${ }^{34}$

The semester approach, as the title suggests, usually consists of two-to-three hour class meetings held once or twice a week for a full semester, eg approximately thirteen to sixteen weeks. While 
student presentations in a workshop format remains the primary focus, the scope for discussion and for faculty lectures and demonstrations is greater than with the intensive approach. ${ }^{35}$ The course is usually coordinated by a full-time member of the law school faculty and may, but not necessarily, access the expertise of the wider legal community. ${ }^{36}$

Andragogically, both methods have their advantages. The intensive approach eliminates student inertia by simply leaving no time for it. ${ }^{37}$ Arguably it facilitates the, "sharp and intensive focus, spontaneity, and possibly the sheer fright that may be necessary to assimilate the skills of a trial advocate". ${ }^{38}$ However, these advantages are overshadowed by the fact that undergraduate law students do not have the experiential basis to quickly absorb the skills being taught. Tuoni notes,

[1]aw students, unlike lawyers, are often literally devoid of any experience in this area before they are plunged into the intensive course. Before students are able to get their bearings straight regarding one aspect of the trial, the course has moved on to the next topic. Before all of the skills can be studied, much less mastered, the course is over. ${ }^{39}$

Some would argue that the student's lack of practical experience is an advantage, rather than a disadvantage, because, "the students usually have so little courtroom experience that bad habits, if they exist, have usually not yet become ingrained; and the learning curve is correspondingly high". ${ }^{40}$ However, the general consensus among legal educators appears to be that the semester approach, which affords the students time for planning, preparation and reflection, is to be preferred. ${ }^{41}$

2 Case files: In the trial advocacy intensive continuing legal education courses run by NITA, the participants work through a number of fact problems. Each problem is structured to highlight a particular skill, for example examination-in-chief, crossexamination, use of visual aids, etc. The course culminates in a mock jury trial based on a complete case file Many of the fact scenarios are set in the mythical community of Nita city. ${ }^{42}$

While the use of numerous, specifically designed, problems may facilitate the teaching of a particular forensic skill, it may achieve this objective at a cost. Berger and Mitchell note,

[w]hile a pure NITA experience will raise novices' self-confidence, make them more comfortable on their feet, and impart various specific 
trial techniques, novices more than likely will still tend to see the trial process as a fragmented bundle of performance skills rather than as a coherent strategic endeavour. ${ }^{43}$

To facilitate strategic planning students should work with the same case file for a substantial period of time, preferably the whole semester. ${ }^{44}$ To inject a breath of reality and relevance into the process, course instructors should develop their own case files, and the fact scenarios should be set in locations the students are familiar with.

The creation of tailor-made materials also facilitates the incorporation of course objectives into the course material. ${ }^{45}$ For example if, at the end of the course, students will be expected to differentiate between "coaching" a witness and assisting that witness to express his or her evidence in a way that accords with his or her true understanding of the facts without being misunderstood, conflicting prior statements which will be dealt with in a conference with the witness can be included in the case file. If the witness is directed by the course instructor to confirm a version of the facts that is inconsistent with the counsel's theory of the case, the temptation to "coach" the witness will be placed squarely before that counsel. ${ }^{46}$ In the constructive feedback which follows the interview, and through the use of video review, the student can evaluate whether he or she has crossed the line between properly briefing a witness and coaching a witness. Of course, such an exercise can also provide the basis for a discussion of the rationale behind the ethical rule which prohibits the coaching of a witness.

3 Student performances: In the NITA model, the emphasis is on performance and feedback. A trial advocacy course should emphasize skills training, however a substantial amount of time should also be set aside for discussion. ${ }^{47}$ How this time will be used will depend on the course objective. ${ }^{48}$

4 Feedback: The delivery of constructive feedback is perhaps the most important, and the most difficult, skill a trial advocacy teacher must master. Both NITA and the Australian Advocacy Institute offer courses which concentrate on this aspect of teaching advocacy skills. ${ }^{49}$ NITA has developed a particularly effective approach which breaks down the provision of constructive feedback into four components: ${ }^{50}$ 
Headline — advise the student what specific point will be dealt with in the feedback;

Play-back - give an example from the student's presentation which illustrates the point identified in the headline;

Prescription - tell the student what techniques can be used to improve the skill;

Rationale - explain to the student why the change is recommended.

When providing such feedback, NITA recommends that the following points should be observed:

a the feedback should be brief, and certainly not longer than the presentation being critiqued;

b the feedback should only deal with one or, at the most, two points. Advocates of the NITA method maintain that students learn as much from listening to the critique of their peer's performances as they do from listening to the critique of their own presentation; ${ }^{51}$

c the feedback should be specific. Comments such as "that was good", or "that wasn't persuasive", are of little benefit to the student; ${ }^{52}$

d explanations from the student should be avoided unless the student's rationale is required by the instructor for the purpose of giving feedback;

e the feedback should be pitched at the student's level, not at the instructor's level;

f the instructor should ensure that the point singled out for comment is a skill the student can improve;

g the instructor should critique the presentation, not the person.

The NITA approach to providing constructive feedback to the student is not the only approach which can be used. ${ }^{53}$ It works well, particularly if the intensive approach is used, but like all methods it should be modified to suit the situation in which it is employed. For example, if the class is small, more than one or two points may be addressed to ensure that the students are receiving feedback on a wide range of techniques. However, as a general guide, I have found the NITA method to be an effective, and educationally sound, approach to providing constructive feedback.

5 Video Review: Videotape reviews provide an excellent 
opportunity for the course instructor to give personal attention to the student. They afford the student the luxury of time to reflect on her or his presentation. They also provide the student with an opportunity to voice any specific concerns that she or he may have concerning her or his performance. The focus of the videotape review should be on the student's style of presentation, not on the substance of the presentation.

Some authors maintain that "there is no other source of evaluation so effective in offering nonjudgmental feedback as videotape review". ${ }^{54}$ Others maintain that the use of videotape review exacerbates the tendency to emphasize performance over substance which, it is argued, is an inherent defect in the simulation/critique method. ${ }^{55}$ I maintain that, if attention is paid to the course content, this latter concern can be addressed. This point will be discussed in greater detail below. At this point suffice it to say that I agree with Westling who maintains that videotaping a student's presentation is "an essential ingredient of a high-quality trial advocacy programme”. ${ }^{56}$

To structure an effective videotape review, NITA makes the following suggestions. ${ }^{57}$

a Personalize the review. Ask the student if she or he has any specific areas or concerns that she or he would like to focus on during the review. Encourage the student to ask questions.

b Stop the tape when giving feedback or responding to a student's question. Do not talk and let tape run at the same time.

c When discussing the feedback provided to the student in the workshop session, deal with the student's perception of that critique. It is the student's perception of what was said, not what was actually said, which is important.

d Ask the student what she or he is going to do differently and end with a forward looking prescription on the points addressed.

6 Assessment: Developing criteria for assessment is extremely difficult. In a course such as trial advocacy, an instructor's assessment may be influenced by the student's personality and by the instructor's own experience and bias. As a consequence, the assessment may be very subjective.

If the course assessment is based solely on the student's 
performance in the workshops and/or in an end of semester trial, this concern is amplified. NITA does not assess the participant's presentation, therefore we cannot look to that model for guidance.

In an attempt to minimize this inherent subjectivity, consideration should be given to including a written component in the assessment. If the assignments are identified only by a student number rather than by the student's name, a degree of objectivity can be incorporated into the process. The written component can take a variety of forms. For example it may consist of a research paper based on an advocacy related topic. Alternatively, it may involve the preparation of a trial notebook which includes a detailed memorandum setting out how the student's theory of the case $^{59}$ will be incorporated into each phase of the trial. ${ }^{60}$ These are but two examples. Ultimately the course objectives will dictate the subject matter of the written component.

If the responsibility for assessing the students is shared, the degree of objectivity is enhanced. In a climate of university budget cutbacks, it is unlikely that more than one fulltime staff member will be allocated to a trial advocacy course. Consideration should be given to tapping the resources of the wider legal community. It has been my experience that practitioners and judges are enthusiastic participants in a trial advocacy course. In addition to the advantages to be gained from an assessment perspective, the exposure to the broad range of approaches, techniques and tactics used by experienced members of the legal profession can be of invaluable assistance to the students.

A word of caution: while properly trained practitioners are a valuable, and cost effective, asset to a trial advocacy course, an advocacy instructor must not lose sight of the fact that practitioners and judges are not teachers. If their services are used, they must receive instruction on how to give constructive feedback, and on how to properly assess students. If they are not amenable to such instruction, their offer to assist should be declined. Old war stories and well intentioned, but destructive, feedback are of little educational benefit to the neophyte advocate.

7 Relieving Courtroom Anxiety: Experienced counsel know that appearing in court can be an addictive cocktail of adrenalin and fear. When these components are in balance, the experience can be exhilarating. When fear dominates, the experience can be 
devastating. Schumacher and Brodsky note,

[o]ne particular environment that elicits an inordinate amount of fear and anxiety is the courtroom proper. Insecurities flourish here. Novices are often driven away permanently, embarrassed by their own incompetence. To many students and young attorneys, this threatening arena is to be avoided under any circumstance. ${ }^{61}$

Advocacy teachers have their own views on how to deal with anxiety reactions to the courtroom environment. My favourite is "preparation, preparation, preparation", however it is unlikely that this provides much comfort to the student who is struck dumb upon hearing the words, "May I have the appearances please". Schumacher and Brodsky advocate a process of "systematic desensitization" which warrants consideration. ${ }^{62}$

Systematic desensitization,

... involves pairing deep relaxation with a series of increasingly potent anxiety-eliciting stimuli. When the subject is successful at imagining a particular stimulus without having anxiety disturb the relaxed state, the subject moves on to the next more disturbing stimulus. Eventually, he or she is able to confront the most threatening stimulus without having an anxiety reaction. ${ }^{63}$

Within the context of advocacy training, "[t]he first step in relieving courtroom anxiety is to construct an anxiety hierarchy by identifying the most anxiety-arousing courtroom situation conceivable, then breaking it down into gradually approaching steps" ${ }^{64}$ For example, if the student's most anxiety-arousing courtroom situation is dealing with the first question from the bench, an anxiety hierarchy may involve the following steps: first reciting his or her address to a friend who will be encouraged to ask questions, then to a friend or relative who is legally trained, then to a Co-counsel, then to someone who is not closely related, and finally to the course instructor in the workshop session. By dealing with each step individually, the student reduces the anxietyproducing stimuli and gains confidence. For some students, this hierarchical approach may be as simple as familiarisation with the courtroom and recitation aloud of important parts of their presentation. For others, extensive anxiety-reduction intervention may be required. ${ }^{65}$ 


\section{Course Content}

It has been asserted above that skills training should remain the primary focus of an undergraduate trial advocacy course, however it should not be the only focus. Not all commentators would agree with the first assertion. Imwinkelried, for example, maintains that trial advocacy teachers should place primary stress on developing their student's analytic skill of fact evaluation. He takes the position that, "a trial practice course stressing primarily forensic techniques does not deserve a place in the law school curriculum". ${ }^{66}$

Allen, on the other hand, does not object to a primary focus on skills training, provided that the teaching of such skills "emanate[s] from a conceptual plane, even if a controversial one, and only if theories justifying the program can be articulated, tested, and justified". ${ }^{67}$ He notes that if trial advocacy is taught "in order to participate in a chain of thought leading to inquiry into the nature of the legal system, then it belongs in a university". ${ }^{68}$ That said, he also maintains that if advocacy skills are taught simply as a technique which can be employed by the advocate to win cases, then such a course is a perversion of the aspiration of the university and has no place in a law school curriculum. ${ }^{69}$

The academic credibility of a trial advocacy course must be assessed within the context of the complete undergraduate curriculum. If this approach is taken, a primary focus on skills training can be justified. Lubet notes,

... there is a danger to ambition, particularly in the course of a single semester. Concepts of truth-seeking, rights distribution, and social accommodation are well-covered in other parts of the law school curriculum. It is not necessary that every single course must exist as a microcosm of the legal academic world. Each class need not be designed to evoke Supreme Court argument or a complete redevelopment of the entire concept of law. Indeed, the greatest failing of the contemporary law school curriculum may well be its lack of calibration. If every class is a recreation of the whole of legal life, there can be little room for students to experience a process of incremental development. The trial advocacy course employs a teaching method, but it also teaches method - the method by which other values can be pursued. ${ }^{70}$

A trial advocacy course which emphasises skills training does warrant a place in the academy provided the students are given the opportunity to explore and question issues beyond the mastery of 
forensic skills. Bearing in mind Lubet's caution, the course instructor must assess what issues can meaningfully be pursued during the course of a single semester.

There are a broad range of topics that warrant consideration in an undergraduate trial advocacy course. ${ }^{71}$ To illustrate how such issues may be dealt with, two topics - the search for truth, and ethics and professionalism - are discussed below.

\section{The Search for Truth: Discovery vs Invention}

Hyman poses an interesting question. When an accomplished litigator articulates an effective theory of the case, conducts the direct examinations with telling detail, and manoeuvres the opposing witnesses into providing discrete and helpful facts, has she invented the case by the artfulness of her work, or has she merely discovered what was present in the facts all along? ${ }^{72}$

One way the tension between discovery and invention can effectively be illustrated is through the use of the videotape of Irving Younger's classic lecture on cross-examination. ${ }^{73}$ Younger tells the story of a man who has been charged with assault for allegedly biting off another man's nose. The prosecution's case rests on the evidence of a single eye-witness who testified in-chief that the accused committed the heinous act. The cross-examination proceeds as follows:

Q Where did it happen?

A In the middle of the field.

Q Where were you?

A On the edge of the field.

Q What were you doing?

A Bird watching.

Q Bird watching?

A Yeah, bird watching.

Q Where were the birds?

A In the trees. 
Q Where were the trees?

A Around the field.

Q So you were looking at the birds in the trees, right?

A Yeah.

Q And the people were fighting in the middle of the field, right?

A Right.

[At this point Younger suggests that the cross-examiner should stop, sit down, and assert in closing argument that the eye-witness could not have seen the assault as his back was to the combatants. Instead the cross-examiner asks the "one question too many”.]

Q Then how come, if you were watching the birds with your back to the defendant and the victim, how come you say that the defendant bit off the victim's nose?

\section{A I saw him spit it out. ${ }^{74}$}

Allan observes that, "I have the impression that this is an oft told tale, but I also have the impression that just as often the storyteller is uneasy telling it, and for good reason". ${ }^{75}$ In Allan's view, the use of the parable detracts from the student's commitment to truth seeking. ${ }^{76}$ Hegland suggests that it inculcates a dogmatic approach to trial practice. ${ }^{77}$ Lubet questions these conclusions and suggests that the parable is not inherently flawed. He argues that it can be used to teach valuable lessons about trial practice and the adversarial system. ${ }^{78}$

This latter point illustrates how the use of such a parable can provide the foundation for a broad-ranging discussion. It illustrates, on one level, the "commandment" that, "Thou shalt not ask the one question too many". On another level it highlights the use of the trial as a vehicle to discover the truth. The students may be asked whether it the responsibility of each advocate to exhaustively seek out the truth, or does the adversarial structure of a trial ensure that the truth will be brought to light? What if cross-examining counsel had not asked the "one question too many"? Does the fact that following the cross-examination the counsel who called the witness would have the opportunity to re-examine make a difference? Lubet suggests that this addresses Allen's concern. ${ }^{79}$ But what if 
the prosecutor is incompetent and neglects to re-examine? Clearly the scope of the discussion is broad and can be conducted on a number of levels.

\section{Professionalism and Ethics}

All the canons of ethics can be boiled down to one: When things are tough, and it looks like somebody is going to jail, make sure it's your client.

\section{Edward Bennett Williams ${ }^{80}$}

Few would argue with the proposition that ethics and professionalism should be addressed in a trial advocacy course. If properly structured, the trial advocacy course should complement the ethics course all law students who intend to enter the legal profession are required to take. This symbiotic relationship will help to achieve the calibration advocated by Lubet, ${ }^{81}$ and will remedy a deficiency inherent in many ethics courses. Tigar identifies this deficiency when he notes that,

[1]aw schools have largely walled off ethics teaching into a separate course; as a consequence, students constantly struggle in their attempts to relate rules to reality. The students' confusion is inevitable if law schools are going to teach only what rules are and what doctrine is, to the exclusion of what lawyers do. ${ }^{82}$

In a trial advocacy course, which emphasises "learning by doing”, there is a broad scope for the infusion of ethics and professionalism. If the case files are properly structured, and if the witnesses participating in the workshop "roleplays" are properly briefed, ethical and professionalism issues can be highlighted and discussed. For example, consider the classic case of the client who changes his story while in the witness box. If such a fact scenario is incorporated into the case file, the person "role-playing" the client can be "coached" by the course instructor to give one version of the facts to his counsel prior to the trial, and a completely different version while under examination-in-chief. How counsel deals with the situation will form the basis of the post-examination class discussion. By injecting an air of reality into the process, an attempt can be made to bridge the gap between theory and practice. 


\section{CONCLUSION}

Forensic skills can be taught, and an undergraduate course in trial advocacy is an appropriate place to teach them. While the simulation/critique method pioneered by NITA provides an excellent model for such a course, it should not be incorporated into the curriculum without modification. If the only focus is skills training, a post-graduate professional legal training course is the more appropriate forum.

A trial advocacy course provides an excellent platform from which to delve into the nature of the legal system. For illustrative purposes, two issues, the search for truth and ethics and professionalism, have been highlighted. These are but two of many. Allen correctly asserts that, "if technical trial skills are not abstracted from their context, virtually the whole of legal life, ..., emerges as the proper object of study for the student of advocacy". ${ }^{83}$

Most students, and many teachers, ascribe to the belief that theory and practice are separate and distinct. Advocacy teachers who attempt to expand the myopic focus on skills training will "soon sense the student's sense of betrayal". ${ }^{84}$ Hegland counsels that,

[t]his false dichotomy should be met head on. Theory informs and guides practice, and theory gives it value. While acknowledging that students have a legitimate and compelling need to learn technique, law teachers should nonetheless assert their belief that they have another compelling, if less immediate and less visible, need - to explore what their use of technique might do to them, to their clients, and to their society. ${ }^{85}$

In a trial advocacy course, students should be given the opportunity to learn not only "how" to conduct a trial, but also "why" their newly acquired skill should be used in a certain way, and "what" effect the use of that skill will have. Through properly structured case files, assignments, and class discussion, students can be given the opportunity to reflect on issues which go beyond the mere mastery of forensic skills.

Australian law schools are in the enviable position of instituting, further developing, and refining trial advocacy courses which suit both the educational objectives of the university and the 

which is uniquely Australian.

* BA, LLB (Alberta), LLM (Qld), Assistant Professor, Bond University, School of Law. I would like to thank Marlene Le Brun of Griffith University and Anita Szabo of Bond University for their comments on the earlier drafts of this article. I alone remain responsible for its contents.

1 By the end of 1993, 9 of the nation's 25 law schools offered a course in Trial Advocacy. Data compiled by the writer is on file at Bond University, School of Law. The term "trial advocacy" is used in its widest sense. It includes any course which focuses on the preparation of a case for trial, and on the presentation of that case before a trier of fact.

2 T Mauet, Can Trial Lawyers Be Taught (May, 1992) 18 Litigation 20, at 22. See also: E Imwinkelried, The Educational Philosophy of the Trial Practice Course: Reweaving the Seamless Web (1989) 23 Ga L Rev 663, at 668.

3 Imwinkelried, supra note 2 at 668.

4 Forward to, T Mauet and L McCrimmon, Fundamentals of Trial Techniques: Australian Edition (Longman Cheshire, 1993), xii.

5 R Carlson, Competency and Professionalism in Modem Litigation: The Role of the Law Schools (1989) 23 Ga L Rev 689, at 697-698.

6 Harvard Law School Association, The Centennial History of the Harvard Law School: 1817-1917 (1918), quoted in Imwinkelried, supra note 2 at 663.

7 W Twining, Pericles and the Plumber (1967) 83 Law Quarterly Rev 396.

8 Id at 397.

$9 \quad$ Id at 398.

10 For example see: G Nash, Should Law Schools Produce Lawyers (May 1991) Aust Law News 19, at 21.

11 For a discussion of the importance of situated knowledge and learning, see: $\mathrm{J}$ Brown, A Collins and P Duguid, Situated Cognition and the Culture of Learning (Jan-Feb 1989) Educational Researcher 32.

12 For example, of those universities that did not offer a Trial Advocacy course prior to 1994, the University of Newcastle School of Law, and Southern Cross University, intend to include such a course in their LLB programme. Supra note 1.

13 E Devitt and H Roland, Why Don't Law Schools Teach Law Students How to Try Lawsuits (1987) 17 William Mitchell Law Rev 445, at 450.

14 Ibid.

15 W Burger, The Special Skills of Advocacy (1973) 42 Fordham Law Rev 227, at 230. See also: G J Tauro, Graduate Law School Training in Trial Advocacy: A New Solution to an Old Problem (1976) Boston Univ Law Rev 635, at 643.

16 T Geraghty, Teaching Trial Advocacy in the 90s and Beyond (1991) 66 Notre Dame Law Rev 687.

171 use the term "closing argument" rather than "closing address" to emphasise to the students the fundamental difference between an opening address and a closing address. Generally see: Mauet and McCrimmon, supra note 4 at 31 .

18 Over a number of days, usually 10, if the intensive approach is used, or over a series of weeks if the semester approach is used. The intensive vs semester approach is discussed in greater detail below.

19 For a further discussion of the NITA method see: Mauet, supra note 2 at 22; S Lubet, Advocacy Education: The Case for Structural Knowledge (1991) 66 Notre Dame Law Rev 721; M Berger and J Mitchell, Rethinking Advocacy Training (1993) 16 American Jour of Trial Advocacy 821. 
20 Most notably Mr Justice George Hampel of the Supreme Court of Victoria and his wife, Felicity Hampel.

21 Australian Advocacy Institute promotional material, (1993) 1, on file at Bond University, School of Law.

22 Ibid.

23 Imwinkelried, supra note 2 at 669; K Hegland, Moral Dilemmas in Teaching Trial Advocacy (1982) 32 Jour of Legal Ed 69; Lubet, supra note 19 at 722-723; Berger and Mitchell, supra note 19 at 822; J A Tanford, What We Don't Teach In Trial Advocacy: A Proposed Course in Trial Law (1991) 41 Jour of Legal Ed 251, at 254-255.

24 Hegland, supra note 23 at 69.

25 Imwinkelried, supra note 2 at 665; Lubet, supra note 19 at 722.

26 Imwinkelried, supra note 2 at 665.

27 Lubet, supra note 19 at 722.

28 Berger and Mitchell, supra note 19 at 830.

29 Lubet, supra note 19 at 722.

40 Ibid See also: Hegland, supra note 23.

31 Hegland, supra note 23 at 69.

32 Lubet, supra note 19 at 733.

33 G Tuoni, Two Models for Advocacy Skills Training in Law Schools - A Critique (1991) 25 Loyola of Los Angeles Law Rev 111, at 113.

34 Id at $113,117-119$.

35 Id at $113-116$.

36 Id at 121. See also: W Westling, The Case for Advocacy Training Within the Law School (1993) 67 ALJ 258, at 259 note 5.

37 Tuoni, supra note 33 at 118.

38 Id at 116.

39 Id at 120. Emphasis in text.

40 Mauet, supra note 2 at 22.

41 For example see: Westling, supra note 36 at 261; Tuoni, supra note 33 at 125; Berger and Mitchell, supra note 19 at 829; J Hyman, Discovery and Invention: The NITA Method in the Contracts Classroom (1991) 66 Notre Dame Law Rev 759, at 780-781.

42 See: D Beskind, A Bocchino, A Ordover and J Seckinger, Problems and Cases in Trial Advocacy, CLE Edition, Vol I and II, 5th ed (NITA, 1988). Copies of these materials are available from NITA, c/o Notre Dame Law School, Notre Dame, Indiana, USA, 46556.

43 Berger and Mitchell, supra note 19 at 829-830.

44 Id at 833-834. See also: Imwinkelried, supra note 2 at 683.

45 On the importance of formulating course objectives, see: A Petter, A Closet Within the House: Learning Objectives and the Law School Curriculum, in N Gold (ed), Essays on Legal Education (Toronto: Butterworths, 1982), at 77; Improving Teaching in Higher Education (University of London Teaching Methods Unit, London: Methuen) at 112.

46 On formulating a theory of the case and preparing witnesses, see: Mauet and McCrimmon, supra note 4 at 7-14.

47 Berger and Mitchell suggest that, "at least one-half of class time should be spent in discussion and exploration of strategic planning”. Berger and Mitchell, supra note 19 at 834.

48 Course objectives may be defined as more or less precise statements of what a student should be able to do as a result of completing the course. Course objectives are distinguished from course aims, which may be defined as broad 
statements of what a course instructor intends to do and hopes that the course will achieve. See: Improving Teaching in Higher Education, supra note 45 at 112.

49 For information regarding these courses, contact: NITA, c/o Notre Dame Law School, Notre Dame, Indiana, USA, 46556; Australian Advocacy Institute, 19 Torrens St, Braddon, ACT, 2601.

50 Generally, see: K Broun, U Lester, M Nelken and J Seckinger, NITA Teacher Training Program Materials, (1st ed, NITA, 1985), and the participant materials distributed at the NITA course entitled, Teaching Advocacy Skills held at Harvard Law School, 27-29 March 1992.

51 Hence, assuming a class of 10 students, if this recommendation is adhered to, at the end of the class the students will have received feedback on between 10 and 20 points.

52 See also: J Brosnahan, suggestions for Enriching the Teaching of Trial Advocacy (1981) 6 American Bar Foundation Research Jour 193, at 210.

53 For example see: ALTA Law Teaching Workshop Materials, Characteristics of Constructive Feedback (1993), at 7.4.

54 J Schumacher and S Brodsky, The Mock Trial: An Exploration of Applications and Dynamics in Interdisciplinary Training (1988) 12 Law and Psych Rev, 79, at 90. See also: Westling, supra note 36 at 262.

55 Lubet, supra note 19 at 722.

56 Westling, supra note 36 at 262.

57 Generally, see: Broun, Lester, Nelken and Seckinger, supra note 50 and the participant materials distributed at the NITA course entitled, Teaching Advocacy Skills held at Harvard Law School, 27-29 March 1992.

58 Tuoni, supra note 33 at 121.

59 For a discussion of case theory and theme, see: E Imwinkelried, The Development of Professional Judgment in Law School Litigation Courses: The Concepts of Trial Theory and Theme (1986) 39 Vanderbilt Law Rev 59; Mauet and McCrimmon, supra note 4 at 7-10.

60 I have tried both of these methods and have been satisfied with the results.

61 Schumacher and Brodsky, supra note 54 at 87.

62 Ibid.

63 Ibid.

64 Ibid.

65 Id at 88.

66 Imwinkelried, supra note 2 at 667.

67 R Allen, NITA and the University (1991) 66 Notre Dame Law Rev, 705, at 717.

68 Ibid.

69 Ibid. See also: A Ordover, Teaching Sensitivity to Facts (1991) 66 Notre Dame Law Rev 813, at 820.

70 Lubet, supra note 19 at 733.

71 Allen throws down the gauntlet when he suggests that, "[t]he trial process is the fulcrum separating the realities of everyday life from the artificial world of the law. It channels the raw materials of the one into the other, and directs the legally refined output back into the larger community. The trial is the gatekeeper of information flowing in both directions, and the techniques of advocacy are central to its functioning. The advocates determine the raw material to be fed into the legal process, shape it, and thus partially but significantly determine the final product. The case is in substantial measure what the advocates make of it, which in turn determines what the legal system does with it. The effect of the trial advocates continues beyond the end of the trial. Virtually all appellate decision making is premised on the record, but the advocate creates the record. 
Thus, if technical trial skills are not abstracted From their context, virtually the whole of legal life, and thus in essence the whole of life, emerges as the proper object of study for the student of advocacy”. Allen, supra note 67 at 711-712. Hyman, supra note 41 at 773.

73 I Younger, The Ten Commandments of Cross-Examination (Videotape, Basic Concepts in the Law of Evidence Series, (1975)); available from NITA, c/o Notre Dame Law School, Notre Dame, Indiana, USA, 46556.

74 Ibid.

75 Allen, supra note 67 at 713.

76 Ibid.

77 Hegland, supra note 23 at 78.

78 Lubet, supra note 19 at 735-737.

79 Id at 737.

80 Quoted in: M Tigar, Voices Heard in Jury Argument: Litigation and the Law School Curriculum (1990) 9 The Rev of Litigation 177, at 196.

81 Supra note 70.

82 Tigar, supra note 80 at 194.

83 Allen, supra note 67 at 712.9

84 Hegland, supra note 23 at 85.

85 Id at $85-86$. 